\title{
항 $\mathrm{TNF}$ 제제와 심한 감염
}

한양대학교 의과대학 류마티스병원 류마티스내과

김 태 환

\section{Anti TNF Therapy and Serious Infection in Rheumatologic Field}

\author{
Tae-Hwan Kim \\ Department of Rheumatology, Hanyang University Hospital for Rheumatic Diseases, \\ Hanyang University, Seoul, Korea
}

\begin{abstract}
류마티스관절염은 만성 골파괴 질환으로 요추를 제외한 관절염 및 관절외 증상을 특징으로 한다. 진 단되면 손목, 손가락 관절변형이 빠른 시간 내에 일 어나 가능하면 초기증상이 있을 때 빨리 진단하여 항류마티스제제(DMARDs) 치료를 시작하는 것을 원 칙으로 한다. MTX를 포함한 많은 약제가 사용되며 여러약제에 효과가 없는 류마티스관절염에서는 90년 대말에 출시된 항 TNF 제제가 널리 보급되어 치료 에 사용되고 있다. 현재까지 1987년 개정된 미국 류 마티스관절염 분류기준이 진단에 많이 사용되고 있 으나 이 진단기준은 이미 $\mathrm{X}$-선 변화가 생긴 관절염 과 다수관절염이 중요시되어 조기진단에는 적합하지 않았다. 류마티스인자, 항 $\mathrm{CCP}$ 항체 검사의 유용성이 여러 논문을 통해 입증되었고 항 TNF 제제를 중심 으로 한 DMARDs가 관절변형 예방에 효과를 보이 면서 2010년 새로 개정된 진단기준이 나오게 되었다 (1). 현재는 가능한 빨리 진단하여 관절 변형 없는 치료에 목표를 두고 있다.
\end{abstract}

강직성척추염은 류마티스관절염과는 발생기전이 달라 말초관절의 관절파괴보다는 천장관절을 포함한 척추관절의 골형성 및 강직이 특징이다. 강직성척추 염 역시 MRI 등장으로 조기 진단이 가능해졌고 일 반 소염제에 효과가 없는 환자에서 항 TNF 제제가 큰 효과를 보여 조기에 질환을 발견하여 변형이 생 기기 전에 치료하고 삶의 질을 높이는 쪽으로 치료 목표가 정해지고 있다 (2).

두 질환 모두 조기에 환자를 구별할 수 있는 검사 방법이 있고 항 TNF 제제라는 강력한 효과를 보이 는 약제가 개발되어 가능한 것이다. 국내에 항 $\mathrm{TNF}$ 제제가 소개된지 약 6년이 지나 많은 임상의사들이 항 TNF 제제에 대해 치료효과를 보고 있지만 처음 소개 당시부터 알려진 결핵을 포함한 감염, 암발생 율에 대해서는 깊이 생각해 볼 필요가 있다.

류마티스학회지 9월호에 Kim 등이 발표한 항 TNF 제제로 치료한 류마티스관절염 환자에서 발생한 심 각한 감염의 발생 빈도는 감염 등 중요한 부작용에

<접수일 : 2010년 12월 10일, 수정일 : 2010년 12월 13일, 심사통과일 : 2010년 12월 13일>

※통신저자 : 김 태 환

서울시 성동구 행당동 17

한양대학교 류마티스병원 류마티스내과

Tel : 02) 2290-9245, Fax : 02) 2298-8231, E-mail : thkim@hanyang.ac.kr 
대해 정리한 논문이다 (3). $\mathrm{Kim}$ 등은 논문에서 류마 티스관절염으로 진단받고 항 $\mathrm{TNF}$ 제제를 3 개월 이 상 투여 받은 환자 175명과 DMARDs만 투약받은 류마티스관절염 환자 375명을 비교하였다. 입원치료 를 요하는 심한 감염을 보이는 환자는 항 $\mathrm{TNF}$ 제제 군에서는 14 예 $(8 \%$, 폐렴, 대상포진, 결핵, 농양과 연 조직염등)로 DMARDs군 19예(5.1\%)에 비해 높았다. 그러나 항 TNF 제제 3제품(etanercept, adalimumab, infliximab)을 비교한 결과는 각 약제마다 중증감염의 차이는 없었다.

항 TNF 제제를 사용하는 환자에서 감염의 발생 빈도는 항 TNF 제제를 사용하는 모든 임상의사의 관심거리이다. 2000년 중반에 나온 자료는 감염발생 빈도를 말해준다. 2006년 JAMA에서 Bongartz 등은 2005 년까지 찾을 수 있는 자료 144 개의 연구논문에 서 자료가 충분한 9 개 논문을 정리한 메타분석에서 항 TNF 제제를 사용하는 군에서는 126 명이 대조군 에서는 26명이 중증감염을 보였다고 발표하면서 항 $\mathrm{TNF}$ 제제 군에서 $\mathrm{OR} 2.0$ (95\% CI, 1.3 3.1)로 높은 감염을 보고 하였고 일반적으로 권하는 양보다 많이 투여된 항 $\mathrm{TNF}$ 제제 군에서 대조군에 비해 OR 2.3 (95\% CI, 1.5 3.6)로 감염 발생이 높다고 발표하였 다 (4). 그후 독일에서 발표된 RABBIT 연구에서는 DMARDs사용군에 비해 etanercept군에서는 OR 2.2 (95\% CI, 0.9 5.4), infliximab군에서는 OR 2.1 (95\% $\mathrm{CI}, 0.8 \sim 5.5)$ 을 발표하였고 영국연구인 $\mathrm{BSRBR}$ 에서 는 DMARDs사용군에 비해 통계적으로 유의한 감염 은 없다고 발표하였다 (5-7). 종합적으로 입원을 요 하지 않는 감염의 빈도는 높지만 심각한 감염의 빈 도는 크게 높지 않다는 의견이다. 대부분 심각한 감 염은 $\mathrm{Kim}$ 등의 연구와 비슷하게 하기도 감염, 대상 포진 감염, 신우신염 및 근골격계 감염순이었다. 그 러나 많은 연구들의 결과가 차이가 있었다.

가장 최근에 발표된 류마티스관절염 환자에서 메 타분석은 항 $\mathrm{TNF}$ 제제 사용 후 심각한 감염 발생비 율은 대조군에 비해 높지 않다는 결과를 보여준다. 8,808 명의 관절염 환자가 참여한 18 개의 연구에서 항 $\mathrm{TNF}$ 제제 사용군이 죽음 $\mathrm{OR} 1.39(95 \% \mathrm{CI}, 0.74$ 2.62), 심각한 부작용 OR $1.11(95 \% \mathrm{CI}, 0.94 \sim 1.32)$, 심각한 감염 $\mathrm{OR} 1.21(95 \% \mathrm{CI}, 0.89 \sim 1.63)$ 의 빈도가 대조군과 큰 차이가 없다고 발표하였다 (8). 국내 자
료를 잘 모아 외국과의 자료를 비교해 보는 것이 의 의가 있겠다.

최근 발표된 대상포진에 대한 연구는 Strangfeld에 의한 것이 있다 (9). 항 TNF 제제 혹은 DMARDs로 치료받는 5,040명 환자를 대상으로 조사하였는데 82 명에서 대상포진이 나타났다. Infliximab 혹은 adalimumab (항체를 사용하는 군)을 사용하는 환자에서 는 39예, etanercept를 사용하는 군에서 23예, DMARDs 군에서 24예가 발생해 발생비율은 치료제로 항체를 사용하는 군에서는 1,000명당 $11.1(95 \%$ CI, 7.9 15.1), etanercept군에서는 8.9 (95\% CI, 5.6 13.3), 일 반적인 DMARDs사용군에서는 $5.6(95 \% \mathrm{CI}, 3.6 \sim$ 8.3)이 발생해 류마티스관절염 환자에서 대상포진의 발생 비율이 높고 infliximab 혹은 adalimumab같이 항체를 사용하는 군에서는 특히 대상포진의 발생에 대해 관심을 요한다고 하였다. Kim 등의 발표도 국 내 류마티스관절염 환자에서 대상포진의 발병비율이 높았지만 항 $\mathrm{TNF}$ 제제간의 차이는 없는 것을 발표 하였다.

국내에서 비교적 많은 175 명을 추적관찰 하였지만 항 $\mathrm{TNF}$ 제제 사용기간이 비교적 짧고, 탈락환자가 많아 아쉬웠고 $\mathrm{Kim}$ 등도 지적했듯이 각 약제들끼리 분석하기에는 치료 숫자가 적었고 대학병원이 아닌 집 근처 병원에 입원한 것이 누락될 가능성 등의 한 계가 있다. 또한 연구가 항 TNF 제제를 투여받는 류마티스관절염 환자만을 대상으로 하였는데 류마티 스관절염 환자는 비교적 항 TNF 제제를 사용하는 나이가 많고, 질병 자체가 $\mathrm{T}$ 세포의 이상으로 해석되 는 면역질환이며, 스테로이드를 포함한 다른 면역억 제제의 사용으로 인해 건강 대조군에 비해 감염의 빈도가 높다는 보고가 있다 (10). 비교적 나이가 젊 고 약제로 인한 감염 가능성이 낮은 환자를 대상으 로 한 연구 및 항 TNF 제제를 많이 사용하는 다른 군인 강직성척추염 환자로 연구 범위를 넓히는 것이 필요하다.

\section{참고문헌}

1) Aletaha D, Neogi T, Silman AJ, Funovits J, Felson DT, Bingham CO 3rd, et al. 2010 Rheumatoid arthritis classification criteria: an American College of 
Rheumatology/European League Against Rheumatism collaborative initiative. Arthritis Rheum 2010;62: 2569-81.

2) Rudwaleit M, Landewé R, van der Heijde D, Listing $\mathrm{J}$, Brandt $\mathrm{J}$, Braun $\mathrm{J}$, et al. The development of Assessment of SpondyloArthritis international Society classification criteria for axial spondyloarthritis (part I): classification of paper patients by expert opinion including uncertainty appraisal. Ann Rheum Dis 2009;68:770-6.

3) Kim HO, Kang KY, Ju JH, Kim HY, Park SH. The incidence of serious infection among rheumatoid arthritis patients exposed to tumor necrosis factor antagonists. J Korean Rheum Assoc 2010;17:246-53.

4) Bongartz T, Sutton AJ, Sweeting MJ, Buchan I, Matteson EL, Montori V. Anti-TNF antibody therapy in rheumatoid arthritis and the risk of serious infections and malignancies: systematic review and meta-analysis of rare harmful effects in randomized controlled trials. JAMA 2006;295:2275-85.

5) Strangfeld A, Listing J. Infection and musculoskeletal conditions: bacterial and opportunistic infections during anti-TNF therapy. Best Pract Res Clin Rheumatol 2006;20:1181-95.
6) Listing J, Strangfeld A, Kary S, Rau R, von Hinueber $\mathrm{U}$, Stoyanova-Scholz M, et al. Infections in patients with rheumatoid arthritis treated with biologic agents. Arthritis Rheum 2005;52:3403-12.

7) Dixon WG, Watson K, Lunt M, Hyrich KL, Silman AJ, Symmons DP, et al. Rates of serious infection, including site-specific and bacterial intracellular infection, in rheumatoid arthritis patients receiving anti-tumor necrosis factor therapy: results from the British Society for Rheumatology Biologics Register. Arthritis Rheum 2006;54:2368-76.

8) Leombruno JP, Einarson TR, Keystone EC. The safety of anti-tumor necrosis factor treatments in rheumatoid arthritis: meta and exposure-adjusted pooled analyses of serious adverse events. Ann Rheum Dis 2009;68:1136-45.

9) Strangfeld A, Listing J, Herzer P, Liebhaber A, Rockwitz K, Richter C, et al. Risk of herpes zoster in patients with rheumatoid arthritis treated with anti-TNF-alpha agents. JAMA 2009;301:737-44.

10) Doran MF, Crowson CS, Pond GR, O'Fallon WM, Gabriel SE. Frequency of Infection in patients with rheumatoid arthritis compared with controls: a population based Study. Arthritis Rheum 2002;46:2287-93. 